\title{
The polymorphism of EGFL6 D535N is not associated with obesity in Chinese children
}

\author{
Chun Lin Wang ${ }^{1 *}$, Yi Dong Wu², Li Liang ${ }^{1}$, Chao Chun Zou', Jun Fen Fu \\ From 7th APPES Biennial Scientific Meeting \\ Nusa Dua, Bali. 14-17 November 2012
}

\section{Objective}

To investigate the association between EGFL6 D535N polymorphism and obesity in Chinese children.

\section{Design}

Case-control study.

\section{Subjects}

A total of 384 obese and 205 healthy children were enrolled as obese and control groups.

\section{Measurements}

The tagged SNP in EGFL6 (rs16979033) was measured by automated platform MassArray. Anthropometric estimates (BMI, BMI Z score, waist circumference, waist-heightratio) and biochemistry marker measurements (fasting glucose, fasting insulin, total cholesterol, triglyceride, HDL-C, non-HDL, HOMA-IR ) were performed.

\section{Results}

The frequencies of the $\mathrm{N}$ allele were $13.9 \%$ in 589 children. Among the obese group, 329 were homozygous for the $535 \mathrm{D}$ allele, 22 girls were heterozygous and 33 were homozygous for the $535 \mathrm{~N}$ allele. In the control group, 173 were homozygous for the 535D allele, 15 girls were heterozygous and 17 were homozygous for the $535 \mathrm{~N}$ allele. The frequencies of the $\mathrm{N}$ allele were $13.5 \%$ in obese group and $14.5 \%$ in control group, having no significant difference $\left(\chi^{2}=0.119, \mathrm{p}=0.730\right)$. The EGFL6 D535N polymorphism was not associated with obesity in either the dominant or recessive model test. The anthropometric estimates and biochemistry markers in patients with EGFL6 353D were not significantly different than those in patients with EGFL6 353N

'Department of Endocrinology, the Children's Hospital of Zhejiang University School of Medicine, Hangzhou, China

Full list of author information is available at the end of the article

\section{Conclusion}

The polymorphism of EGFL6 D535N was very common in Chinese children. EGFL6 D535N polymorphism was not associated with obesity in Chinese children and it may not be a cause of childhood obesity.

Authors' details

${ }^{1}$ Department of Endocrinology, the Children's Hospital of Zhejiang University School of Medicine, Hangzhou, China. ${ }^{2}$ The Key Laboratory of Reproductive Genetics (Zhejiang University), Ministry of Education Hangzhou, China.

Published: 3 October 2013

doi:10.1186/1687-9856-2013-S1-P106

Cite this article as: Wang et al:: The polymorphism of EGFL6 D535N is not associated with obesity in Chinese children. International Journal of Pediatric Endocrinology 2013 2013(Suppl 1):P106.
Submit your next manuscript to BioMed Central and take full advantage of:

- Convenient online submission

- Thorough peer review

- No space constraints or color figure charges

- Immediate publication on acceptance

- Inclusion in PubMed, CAS, Scopus and Google Scholar

- Research which is freely available for redistribution
C Biomed Central 